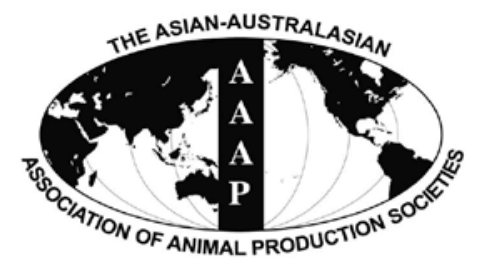

Asian-Aust. J. Anim. Sci.

Vol. 25, No. 2 : 200 - 206

February 2012

www.ajas.info

http://dx.doi.org/10.5713/ajas.2011.11318

\title{
Physiological Changes in Jeju Crossbred Riding Horses by Swim Training
}

\author{
Ok-Deuk Kang, Youn-Chul Ryu, Young-Min Yun ${ }^{1}$ and Min-Soo Kang* \\ Division of Biotechnology, Jeju National University, Jeju 690-756, Korea
}

\begin{abstract}
The changes in physiologic parameters by swim exercise duration were examined in five female well-trained Jeju crossbred riding horses that had riding experience of more than three years without swim training experience. The horses were performed with swim exercise for $10 \mathrm{~min}(60.0 \mathrm{~m} / \mathrm{min})$ once a day for 14 days. Physiologic characteristics and haematic parameters were measured before swimming, immediately after swimming, and after a 10 min rest at first day $\left(D_{0}\right), 7$ days $\left(D_{7}\right)$, and 14 days $\left(D_{14}\right)$ of training. After 14 days of swim training, heart rate $(p<0.05)$, blood glucose $(p<0.05)$, lactate concentration $(p<0.001)$, packed cell volume $(\mathrm{p}<0.01)$, and hemoglobin $(\mathrm{p}<0.01)$ measured immediately after swim and after $10 \mathrm{~min}$ rest showed significant lower values than those of $\mathrm{D}_{0}$. The results illustrate the benefits of swim training for riding horses and the need for the establishment of swimming routines of appropriate duration and intensity to maximize the advantages of swim training. (Key Words : Equine, Physiologic Parameters, Exercise, Swim, Training)
\end{abstract}

\section{INTRODUCTION}

Swimming is a well established method amongst trainers and owners, often used as a means of conditioning and rehabilitating horses. Most importantly, it provides a low risk of injury as the horse is not subjected to the pounding that track or field work can have on the joint.

Swimming has also been found to be highly effective for treating horse diseases such as arthritis and tendonitis. As a form of exercise, swimming is used with horses as a part of their training regimen, particularly when lameness exists (Thomas et al., 1980). In addition to building basic muscle tone, it provides exercise, promotes the development of underutilized muscles, and expands and strengthens the heart and lungs.

Water power, buoyancy, and water resistance influence the effects of swim training. This type of training provides a considerable amount of exercise in a short amount of time as a result of the increased intensity and decreased impact on the legs (Waran, 2002). Also, water power develops pectoral muscles by enhancing breathing and increasing

\footnotetext{
* Corresponding Author : Min-Soo Kang. Tel: +82-64-754-3337, Fax: +82-64-725-2403, E-mail: mskang@cheju.ac.kr

${ }^{1}$ College of Veterinary Medicine, Jeju National University, Jeju 690-756, Korea.
}

Received September 2, 2011; Accepted October 31, 2011 lung capacity (Pluim et al., 2000; Fagard, 2003). Moreover, the power of pushing through water resistance builds up olfactory groove muscles, as every muscle of the body is used during active propelling exercise. Therefore, due to its effects on enhancing heart and lung function, and physical fitness in general, propulsion swim training is frequently utilized with horses to increase their endurance (Davie et al., 2008).

Prior studies have concentrated on how swim training affects the equine cardiovascular and respiratory systems (Asheim et al., 1970; Misumi et al., 1994; Jones et al., 2002). Research in both humans and horses supports the existence of a relationship between left ventricular mass and maximal oxygen uptake. Equine studies using echocardiography also show a correlation between heart score and maximal oxygen uptake (Young et al., 2002).

Swimming is an excellent exercise for enhancing the endurance of racehorses rather than addressing slow twitch muscle fibers. Previous studies have investigated the effectiveness of a swimming exercise test for evaluating changes in performance measures, skeletal muscle composition (Misumi et al., 1994, 1995), and respiratory function (Hobo et al., 1998). However, previous studies, have not established the physiological benefits of swim training for horses; therefore, the aim of this study was to examine the effect of swim training duration on physiological characteristics in Jeju crossbred riding horses. 


\begin{tabular}{|c|c|c|c|c|} 
Period 1 & \multicolumn{2}{|c|}{ Period 2 } & \multicolumn{2}{c|}{ Period 3 } \\
\hline $\begin{array}{c}\text { Measurement } \\
\text { of horses }\end{array}$ & $\begin{array}{c}\text { Swim Training } \\
\text { for 7 days } \\
\text { (10 min once a day) }\end{array}$ & $\begin{array}{c}\text { Measurement } \\
\text { of horses }\end{array}$ & $\begin{array}{c}\text { Swim Training } \\
\text { for 7 days } \\
(10 \mathrm{~min} \text { once a day })\end{array}$ & $\begin{array}{c}\text { Measurement } \\
\text { of horses }\end{array}$ \\
\hline$D_{0}$ & $\underset{20 \text { laps }(60.0 \mathrm{~m} / \mathrm{min})}{\longrightarrow}$ & $D_{7}$ & $\underset{20 \text { laps }(60.0 \mathrm{~m} / \mathrm{min})}{\longrightarrow}$ & $D_{14}$
\end{tabular}

Figure 1. Diagram of experimental design.

\section{MATERIALS AND METHODS}

\section{Animals}

A total of five Jeju crossbred horses (Thoroughbredx Jeju native) from riding centers on Jeju Island were used for this study. The horses participated five females, weighing $318 \pm 18.5 \mathrm{~kg}$ with a mean age of $6.6 \pm 1.3$ years.

The horses had riding experience more than three years. However, they have never tried swimming training. All horses were clinically healthy prior to the swimming experience. This study was approved by the Animal Ethics Committee of Jeju National University, Korea.

\section{Experimental design}

This study was performed to determine effects on physiologic variables according to swim training duration. The training track used had a circumference of $30 \mathrm{~m}$, a depth of $1.8 \mathrm{~m}$ and a width of $3 \mathrm{~m}$. Training was performed for 10 min once a day for 14 days. Each horse completed 20 laps $(60.0 \mathrm{~m} / \mathrm{min})$ for swim training (Figure 1$)$.

The swim training durations evaluated were: first day $\left(D_{0}\right), 7$ days $\left(D_{7}\right)$, and 14 days $\left(D_{14}\right)$ of training. Physiological characteristics, blood glucose, lactate concentration, packed cell volume (PCV), total protein (TP), and hemoglobin $(\mathrm{Hb})$ were measured before swimming, immediately after swimming, and after a 10 min rest. Prior studies, as to $15 \mathrm{~min}$ cool down exercise groups, level of lactic acid as indicator of fatigue substance was recovered to $75 \%, 58 \%, 45.3 \%$ respectively in TR15, WR15 and R15 group, which means that recovery was efficiently achieved in active groups than passive groups (Kang et al., 2011). Therefore, the rest period consisted of trotting on a treadmill.

\section{Heart rate (HR) measurements and blood analysis}

HR was also measured before swimming, immediately after swimming, and after a 10 min rest with a T31 Polar transmitter (Polar Equine, Finland). Blood samples were taken from the jugular vein with a 21-gauge needle using Vacutainer $^{\circledR}$ collection tubes. Blood lactate concentrations were analyzed using an LT-1710 L-Pro lactate analyzer (ARKRAY Inc., Japan) and glucose concentrations were calculated using the Accu-Chek Go system (Roche, Germany). PCV, TP, and Hb were analyzed at the clinical pathology laboratory of the veterinary teaching hospital at Jeju National University.

\section{Statistical analysis}

Data were analyzed using a two-way analysis of variance (ANOVA) for repeated measures with points before swim, after swim, and $10 \mathrm{~min}$ after rest at training periods $D_{0}, D_{7}$, and $D_{14}$. All data is reported as means $\pm S D$ with a significance level of $\mathrm{p}<0.05$ using SAS version 8 (SAS Institute Inc., Cary, NC, USA). Person correlation coefficients were evaluated to describe the relationship between variables using partial correlation coefficients (CORR procedure of SAS).

\section{RESULTS}

\section{Swim training}

The aim of this study was to evaluate the physiologic effects of swim training over a two-week duration. The mean speed of the horses during training was $60.0 \mathrm{~m} / \mathrm{min}$. This study was conducted to determine effects on physiologic variables according to swim training duration. The training track used had a circumference of $30 \mathrm{~m}$, a depth of $1.8 \mathrm{~m}$ and a width of $3 \mathrm{~m}$ and was performed for 10 min once a day for 14 days.

\section{Heart rate}

After swim training HR was highest immediately after exercise but gradually decreased $(p<0.001)$. At 10 min after rest, $D_{7}$ and $D_{14}$ showed significant decreases in $H R$ compared to $\mathrm{D}_{0}$ (Figure $2 \mathrm{~A}$ ). HR was positively related to lactate $(r=0.719 ; \mathrm{p}<0.001)$, glucose $(r=0.574 ; \mathrm{p}<0.01)$, and PCV $(r=0.473$; $<<0.001)$. 


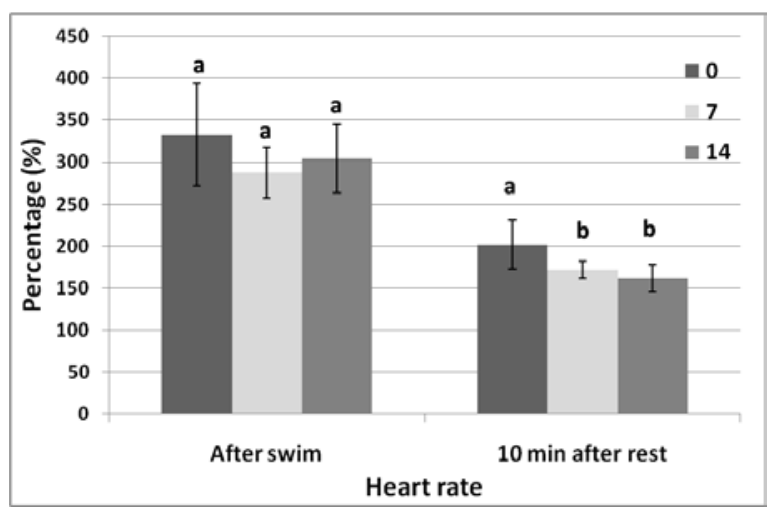

(A)

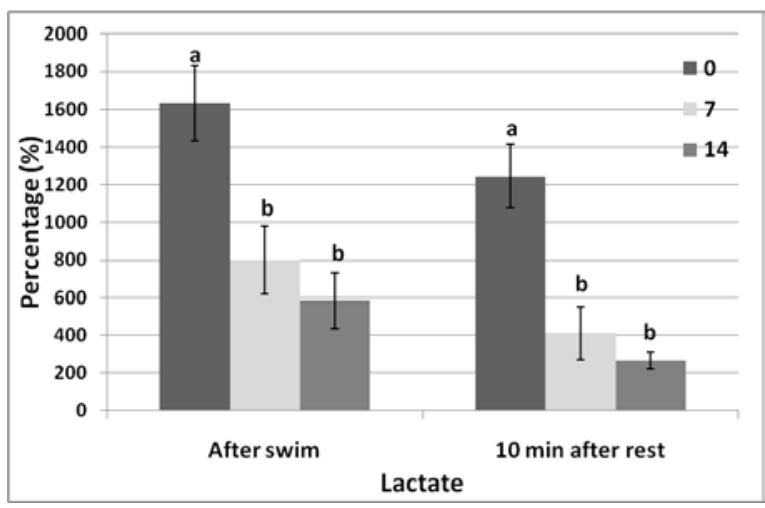

(C)

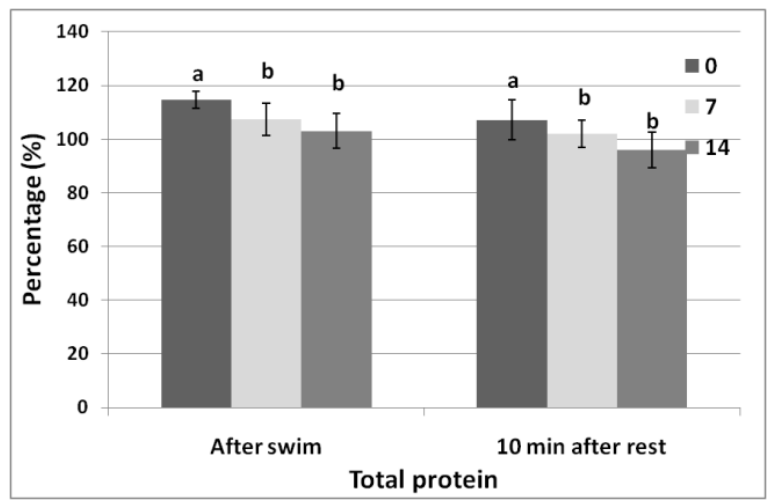

(E)

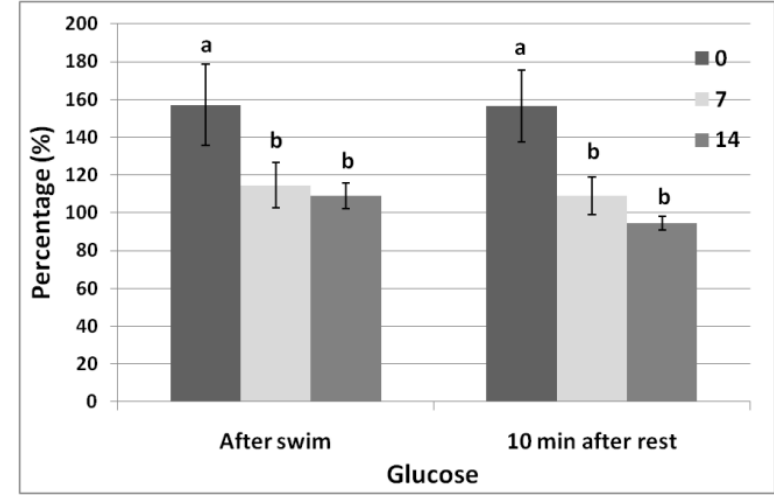

(B)

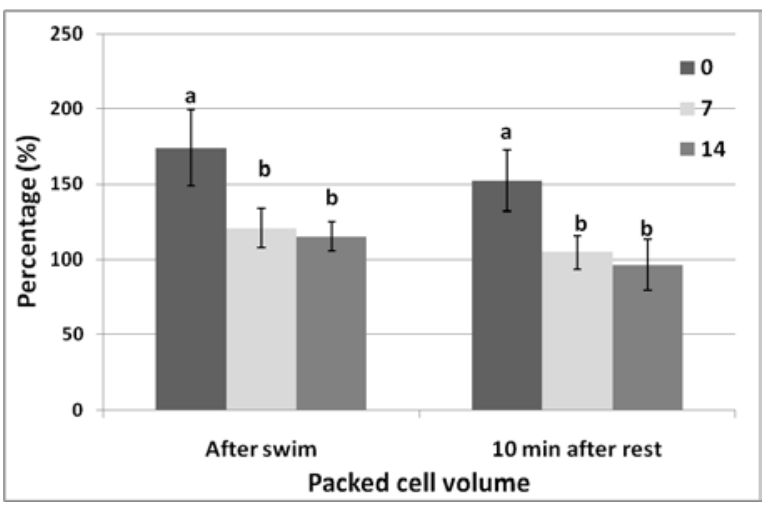

(D)

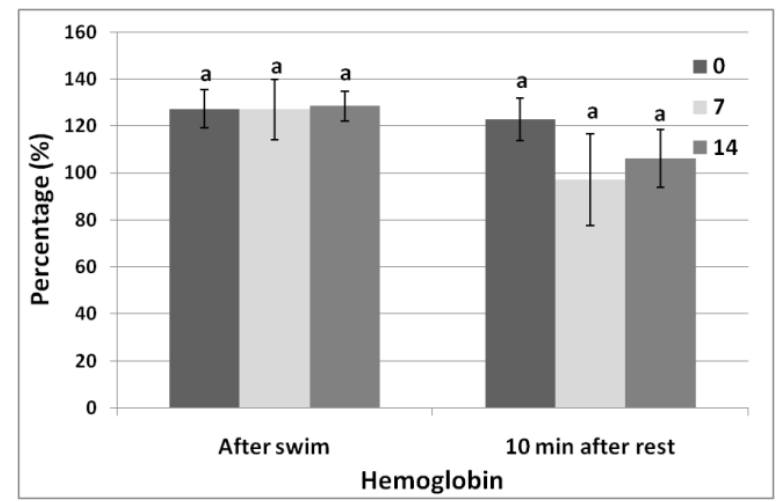

(F)

Figure 2. Relative changes of physiologic and haematic parameters of horses after swim training. A, heart rate; B, glucose concentration; C, lactate concentration; D, packed cell volume; E, total protein; F, hemoglobin. ${ }^{\mathrm{a}, \mathrm{b}}$ Means with different superscripts significantly differ $(p<0.05)$. 
Table 1. Effect of swim training duration on physiologic variables of horses

\begin{tabular}{|c|c|c|c|c|c|}
\hline \multirow{2}{*}{ Variables } & \multirow{2}{*}{ Measurement time } & \multicolumn{3}{|c|}{ Swim training duration (days) } & \multirow{2}{*}{ Significance } \\
\hline & & 0 & 7 & 14 & \\
\hline \multirow{3}{*}{$\begin{array}{l}\text { Heart rate } \\
\text { (beats/min) }\end{array}$} & Before swim & $50.80^{\mathrm{a}} \pm 20.76$ & $49.60^{\mathrm{a}} \pm 10.45$ & $44.00^{\mathrm{a}} \pm 4.24$ & NS \\
\hline & After swim & $148.8^{\mathrm{a}} \pm 19.0$ & $124.2^{\mathrm{b}} \pm 19.1$ & $132.0^{\mathrm{ab}} \pm 27.6$ & $*$ \\
\hline & 10 min after rest & $93.4^{\mathrm{a}} \pm 30.9$ & $82.8^{a b} \pm 11.8$ & $70.0^{\mathrm{b}} \pm 10.4$ & * \\
\hline \multirow{3}{*}{$\begin{array}{l}\text { Blood glucose concentration } \\
(\mathrm{mmol} / \mathrm{L})\end{array}$} & Before swim & $80.60^{\mathrm{a}} \pm 21.00$ & $97.60^{\mathrm{a}} \pm 17.22$ & $86.60^{\mathrm{a}} \pm 11.76$ & NS \\
\hline & After swim & $118.4^{\mathrm{a}} \pm 18.2$ & $110.0^{\mathrm{a}} \pm 21.5$ & $93.6^{\mathrm{b}} \pm 11.4$ & $*$ \\
\hline & 10 min after rest & $116.6^{\mathrm{a}} \pm 18.6$ & $104.6^{\mathrm{a}} \pm 17.6$ & $82.4^{\mathrm{b}} \pm 16.0$ & $* * *$ \\
\hline \multirow{3}{*}{$\begin{array}{l}\text { Blood lactate concentration } \\
(\mathrm{mmol} / \mathrm{L})\end{array}$} & Before swim & $0.80^{\mathrm{a}} \pm 3.20$ & $0.30^{\mathrm{a}} \pm 2.03$ & $0.22^{\mathrm{a}} \pm 1.02$ & NS \\
\hline & After swim & $13.03^{\mathrm{a}} \pm 3.17$ & $6.40^{\mathrm{b}} \pm 2.91$ & $4.66^{\mathrm{b}} \pm 2.37$ & $* * *$ \\
\hline & 10 min after rest & $9.96^{\mathrm{a}} \pm 4.57$ & $3.28^{\mathrm{b}} \pm 2.37$ & $2.12^{\mathrm{b}} \pm 0.76$ & $* * *$ \\
\hline
\end{tabular}

Levels of significance: NS $=$ Not significant; $* \mathrm{p}<0.05 ; * * * \mathrm{p}<0.001$.

${ }^{a, b}$ Means with different superscripts in the same row significantly differ $(\mathrm{p}<0.05)$.

\section{Glucose}

The differences in blood glucose levels among the training periods are shown in Table 1 and Figure 2B. The $\mathrm{D}_{14}$ stage had significantly lower blood glucose levels than $\mathrm{D}_{0}$ and $\mathrm{D}_{7}(\mathrm{p}<0.001)$. In this study, criteria of comparison employed to measure the change in recovery rate are fixed to $100 \%$, which is the condition right after exercise. Figure 2 shows the recovery rate according to the type and time of rest and all figures are converted into a percentage. Blood glucose levels showed a strong relationship with lactate levels ( $r=0.716 ; \mathrm{p}<0.001)$.

\section{Lactate}

Blood lactate levels before training at all stages were less than $1 \mathrm{~mol} / \mathrm{L}$ and all stages experienced the greatest increase in blood lactate immediately after training $(\mathrm{p}<$ 0.001 ), and then tended to decrease with the training period. In particular, the $\mathrm{D}_{7}$ stage had significantly reduced concentrations compared to $\mathrm{D}_{0}$ (Table 1 and Figure 2C). Blood lactate levels were positively related to PCV, $\mathrm{Hb}$, and TP.

\section{Packed cell volume}

Table 2 shows the PCV in relation to training periods at different time points. $\mathrm{D}_{7}$ and $\mathrm{D}_{14}$ had lower PCV values than $\mathrm{D}_{0}$ after training $(\mathrm{p}<0.001)$. Comparing of according to swim training duration in immediately after training and 10 min rest, in $D_{7}$ and $D_{14}$, all stages showed similar levels. PCV showed a positive relationship with TP ( $r=0.521$; $\mathrm{p}<0.001)$, and $\mathrm{Hb}(r=0.529 ; \mathrm{p}<0.001)$.

\section{Total protein}

The levels of blood TP for the training period at the different time points are shown in Table 2. The level of TP did not significantly differ among the training periods. Also, $10 \mathrm{~min}$ after rest, all levels recovered to what they were before the start of training; however, recovery rates of TP immediately after training was more efficient at $\mathrm{D}_{7}$ and $\mathrm{D}_{14}$ than at $\mathrm{D}_{0}$.

\section{Hemoglobin}

$\mathrm{Hb}$ values at $\mathrm{D}_{7}$ and $\mathrm{D}_{14}$ were significantly decreased compared to $D_{0}$, but $D_{7}$ values recovered during the rest

Table 2. Effect of swim training duration on haematic parameters of horses

\begin{tabular}{|c|c|c|c|c|c|}
\hline \multirow{2}{*}{ Variables } & \multirow{2}{*}{ Measurement time } & \multicolumn{3}{|c|}{ Swim training duration (d) } & \multirow{2}{*}{ Significance } \\
\hline & & 0 & 7 & 14 & \\
\hline \multirow{3}{*}{$\begin{array}{l}\text { Packed cell volume } \\
\text { (\%) }\end{array}$} & Before swim & $35.80^{\mathrm{a}} \pm 7.15^{\mathrm{A}}$ & $41.20^{\mathrm{a}} \pm 15.15$ & $36.80^{\mathrm{a}} \pm 5.16$ & NS \\
\hline & After swim & $59.40^{\mathrm{a}} \pm 8.68$ & $45.40^{\mathrm{b}} \pm 4.35$ & $42.40^{\mathrm{b}} \pm 10.8$ & $* * *$ \\
\hline & 10 min after rest & $52.00^{\mathrm{a}} \pm 8.68$ & $37.80^{\mathrm{b}} \pm 9.03$ & $37.60^{\mathrm{b}} \pm 10.59$ & $* *$ \\
\hline \multirow{3}{*}{$\begin{array}{l}\text { Total protein } \\
\text { (g/dl) }\end{array}$} & Before swim & $7.04^{\mathrm{a}} \pm 0.71$ & $6.88^{\mathrm{a}} \pm 1.04$ & $7.12^{\mathrm{a}} \pm 0.86$ & NS \\
\hline & After swim & $8.08^{\mathrm{a}} \pm 0.83$ & $7.30^{\mathrm{a}} \pm 0.64$ & $7.32^{\mathrm{a}} \pm 1.01$ & NS \\
\hline & 10 min after rest & $7.54^{\mathrm{a}} \pm 0.86$ & $6.96^{\mathrm{a}} \pm 0.73$ & $6.82^{\mathrm{a}} \pm 0.84$ & NS \\
\hline \multirow{3}{*}{$\begin{array}{l}\text { Hemoglobin } \\
\text { (g/dl) }\end{array}$} & Before swim & $18.33^{\mathrm{a}} \pm 0.11$ & $11.52^{\mathrm{b}} \pm 2.25$ & $13.66^{\mathrm{ab}} \pm 4.55$ & $*$ \\
\hline & After swim & $23.33^{\mathrm{a}} \pm 0.72$ & $14.38^{\mathrm{b}} \pm 4.77$ & $17.68^{\mathrm{b}} \pm 6.16$ & $* *$ \\
\hline & $10 \mathrm{~min}$ after rest & $22.53^{\mathrm{a}} \pm 1.15$ & $11.06^{\mathrm{b}} \pm 5.11$ & $14.90^{\mathrm{b}} \pm 6.92$ & $* * *$ \\
\hline
\end{tabular}

Levels of significance: NS = Not significant; ${ }^{*} \mathrm{p}<0.05 ;{ }^{* *} \mathrm{p}<0.01 ; * * * \mathrm{p}<0.001$.

${ }^{\mathrm{a}, \mathrm{b}}$ Means with different superscripts in the same row significantly differ $(\mathrm{p}<0.05)$. 
Table 3. Correlation coefficients $(r)$ among physiologic and haematic parameters of horses

\begin{tabular}{llllll}
\hline Heart rate & HR & Glucose & Lactate & PCV & TP \\
\hline Glucose & $0.574^{* *}$ & & & & \\
Lactate & $0.719^{* * *}$ & $0.716^{* * *}$ & & & \\
Packed cell volume & $0.473^{* * *}$ & $0.423^{* *}$ & $0.639^{* * *}$ & $0.521^{* * *}$ & $0.529^{* * *}$ \\
Total protein & $0.424^{* *}$ & 0.126 & $0.525^{* * *}$ & 0.137 \\
Hemoglobin & 0.241 & 0.229 & 0.529
\end{tabular}

Levels of significance: ** $\mathrm{p}<0.01 ; * * * \mathrm{p}<0.001$.

period. Hb levels were positively related to lactate $(r=$ 0.525; $\mathrm{p}<0.001)$ and PCV $(r=0.529 ; \mathrm{p}<0.001)$.

\section{DISCUSSION}

It is well known that high intensity training results in an increase in the oxidative enzyme activity of muscle (Pluim et al., 2000; Fagard, 2003; Davie et al., 2008). Muscle and blood homeostasis may dramatically change under exercise conditions (Westerblad and Allen, 2003) and continuous efforts cannot be effectively applied unless an adequate restoration of homeostasis occurs (Toubekis et al., 2008).

Certain hematological adaptations are necessary to guarantee an adequate supply of oxygen and blood-borne substrates to active muscles during exercise and for the removal of metabolites (Piccione et al., 2007). The body must be properly prepared if the benefits of exercise are to be garnered safely. This study was performed to identify physiological changes in horses during two weeks of swim training. Each animal circled the swim track for 20 laps $(60.0 \mathrm{~m} / \mathrm{min})$ during the swim training. The results indicated that changes in physiological traits following swim training were dependent upon the training period.

Immediately after exercise, there were significant differences in $\mathrm{HR}$ during the $\mathrm{D}_{7}$ training period compared to $\mathrm{D}_{0}(\mathrm{p}<0.001)$. If the rate prior to exercise was considered as $100 \%$, when compared to immediately after exercise and after a $10 \mathrm{~min}$ rest, the $\mathrm{D}_{14}$ stage showed the fastest decrease in HR ( 142\%). In this experiment, the pretraining HR ranged from 44 to 51 beats/min and posttraining from 124 to 149 beats/min. The HR (170-180 beats/min; $\max 75-80 \%$ ) of a race horse indicates that anaerobic metabolism occurs greatly during exercise due to the significant increase in lactate concentration to threshold levels following anaerobic exercise (Gondim et al., 2007; Ferraz et al., 2008). It is considered that the training of a riding horse is less restrictive than that of a racehorse in terms of speed during ordinary training procedures.

Regarding blood glucose concentration after exercise, $\mathrm{D}_{0}$ and $\mathrm{D}_{7}$ stages had similar values but $\mathrm{D}_{14}$ had significantly different values $(\mathrm{p}<0.001)$. The decreasing rates at $D_{14}, D_{7}$, and $D_{0}$ stages were approximately $14 \%$, $5.58 \%$, and $0.58 \%$, respectively. It is suggested that the glucose level in the $\mathrm{D}_{14}$ stage is the result of fast recovery from high-intensity training. Previous studies showed an increase in blood lactate concentration in anaerobic metabolism of horses (Ferraz et al., 2007, 2008; Piccione et al., 2010).

Onset of blood lactate accumulation ( $4 \mathrm{mmol} / \mathrm{L}$ ) has been used as a criterion to evaluate the exercise capacity of horses (Gondim et al., 2007; Lindner et al., 2009; Piccione et al., 2010). Thus, lactate production and removal are very important during anaerobic exercise and relevant to the interpretation of blood lactate concentrations (Gondim et al., 2007). The results in this study showed the marked increase of blood lactate level immediately after training $(\mathrm{p}<0.001)$.

Blood lactate concentration tended to decrease depending on the training period. In particular, it was significantly reduced at $D_{7}$ compared to $D_{0}$. When comparing each value immediately after exercise, $\mathrm{D}_{0}, \mathrm{D}_{7}$, and $\mathrm{D}_{14}$ lactate production was $1,600 \%, 800 \%, 580 \%$, respectively. These results indicated that lactic acid formation diminished as the duration of training increased. In addition, recovery rate at $D_{14}$ was even faster than that at $D_{0}$. Both $D_{7}$ and $D_{14}$ lactate levels decreased below 4 $\mathrm{mmol} / \mathrm{L}$ after a $10 \mathrm{~min}$ rest, which showed no excess recovery. The reduction of blood lactate reflects the improved metabolic efficiency of the horses. Kang et al. (2011) reported the lactate concentration level recovered to the threshold of $4 \mathrm{mmol}$ after $15 \mathrm{~min}$ rest in the highintensity exercise (Kang et al., 2011). Also, Piccione et al. (2010) reported on a trot group with a very low lactate accumulation level after exercise (Piccione et al., 2010).

In this study, PCV, an estimate of the volume of red blood cells, was used to evaluate dehydration and anemia. Typically, the optimum level of PCV in horses is close to $40 \%$, and levels below $32 \%$ or above $48 \%$ indicate problems. Below $30 \%$ of PCV is considered anemic, and efforts should be made to identify the reason for the lack of red cells. This study identified significant changes in PCV immediately after training and after a 10 min rest compared to levels prior to training.

TP of blood was also measured as an aid in estimating hydration status. There were no significant differences when comparing stages. Hb levels showed a quick recovery rate compared to levels prior to training. Also, when 
comparing immediately before and after the training, the recovery rate of $\mathrm{Hb}$ immediately following exercise dramatically declined compared to what it was before exercise. Taken together, the changes realized after training demonstrate the effects of swimming on physiological adaptation of the horses. Jones et al. (2002) found peak expiratory pressures in horses to be higher during swimming than galloping and that horses breath five times slower while swimming than galloping.

In horses, aerobic training escalates cardiopulmonary function, muscular strength, and blood release rate by strengthening the heart, which causes less fatigue despite rapid running. In addition, anaerobic training gives rise to rapid fatigue recovery by decreasing physical energy output when the horse speeds up enhancing removal of accumulated fatigue materials. Therefore, aerobic and anaerobic methods should be combined in horse training. This study has great significance in that it is the very first study to consider the effectiveness of swim training on riding horses. Equine blood lactate concentration is generally below $1 \mathrm{mmol} / \mathrm{L}$. With increased exercise intensity, concentrations below $4 \mathrm{mmol} / \mathrm{L}$ indicate aerobic exercise whereas levels above $4 \mathrm{mmol} / \mathrm{L}$ indicate anaerobic exercise.

According to a study by Knudsen and Jrgensen (2000), swimming was observed to decrease lactic acid formation more than an average quick pace on land, and as such is considered a viable substitute training method to reduce injuries resulting from excessive tension. In addition, swimming is seen as an effective means to train the cardiovascular system as well as both aerobic and anaerobic muscle capacity. Davie et al. (2008) also reported that swimming produced less lactic acid formation than track training. Knudsen and Jrgensen (2000) suggested that swimming could be substituted for the traditional training of horses in order to improve the cardiovascular system and the aerobic and anaerobic capacities of the musculature. Swim training is considered an effective method in terms of maintaining or developing equine cardiovascular function.

In conclusion, after 14 days of swim training, heart rate $(\mathrm{p}<0.05)$, blood glucose $(\mathrm{p}<0.05)$, lactate concentration $(\mathrm{p}<0.001)$, packed cell volume $(\mathrm{p}<0.01)$, and hemoglobin $(\mathrm{p}<0.01)$ measured immediately after swim and after $10 \mathrm{~min}$ rest showed significant lower values than those of $\mathrm{D}_{0}$. Horses in this study demonstrated rapid lactate recovery (below $4 \mathrm{mmol} / \mathrm{L}$ ) during both swim training sessions after a 10 min rest (Table 1). Lactate concentrations at $D_{0}, D_{7}$, and $\mathrm{D}_{14}$ immediately after exercise were $13.03 \pm 3.17$, $6.40 \pm 2.91$, and $4.66 \pm 2.37 \mathrm{mmol} / \mathrm{L}$. Lactic acid formation dramatically diminished compared to levels prior to swimming, indicating a large difference depending on training periods. These results illustrate the benefits of swim training for riding horses and the need for the establishment of swimming routines of appropriate duration (despite the short period of two weeks) and intensity to maximize the advantages of swim training.

\section{ACKNOWLEDGEMENT}

This work was partially supported by the Equine Industry Research Center and the Research Institute for Subtropical Agriculture and Biotechnology of Jeju National University, Korea.

\section{REFERENCES}

Asheim, A., O. Knudsen, A. Lindholm, C. Rülcker and B. Saltin. 1970. Heart rate and blood lactate concentrations of standardbred horses during training and racing. J. Am. Vet. Med. Assoc. 157:304-312.

Davie, A., C. J. Savage and L. Fennell. 2008. The effect of swimming training on the cardiac dimensions in thoroughbred horses. Rural Industries Research and Development Corporation. RIRDC Publication, Australia, pp. 3-11.

Fagard, R. 2003. Education in heart: Athlete's heart. Heart 89: 1455-1461.

Ferraz, G. C., A. R. Teixeira-Neto, F. H. F. D’Angelis, J. C. Lacerda-Neto and A. Queiroz-Neto. 2007. Effect of acute administration of clenbuterol on athletic performance in horses. J. Equine Vet. Sci. 27:446-449.

Ferraz, G. C., F. H. F. D’Angelis, A. R. Teixeira-Neto, D. V. V. Freitas, J. C. Lacerda-Neto and A. Queiroz-Neto. 2008. Blood lactate threshold reflects glucose responses in horses submitted to incremental exercise test. Arquivo Brasileiro de Medicina Veterinária 60:256-259.

Gondim, F. J., C. C. Zoppi, L. Pereira-da-Silva and D. V. de Macedo. 2007. Determination of the anaerobic threshold and maximal lactate steady state speed in equines using the lactate minimum speed protocol. Comp. Biochem. Physiol. 146:375380.

Hobo, S., K. Yoshida and T. Yoshihara. 1998. Characteristics of respiratory function during swimming exercise in thoroughbreds. J. Vet. Med. Sci. 60:687-689.

Jones, J. H., K. S. Cox, T. Takahashi, A. Hiraga, T. B. Yarbrough and J. R. Pascoe. 2002. Heterogeneity of intrapleural pressures during exercise. Equine Vet. J. 34:391-396.

Kang, O. D., Y. C. Ryu, Y. M. Yun and M. S. Kang. 2011. Effects of cooldown methods and durations on equine physiological traits following high-intensity exercise. Livest. Sci. (In press).

Knudsen, D. M. and P. F. Jrgensen. 2000. Swimming training in horses compared with racing or riding training. J. Dansk Veterinærtidsskrift 83:6-10.

Lindner, A., H. Mosen, S. Kissenbeck, H. Fuhrmann and H. P. Sallmann. 2009. Effect of blood lactate-guided conditioning of horses with exercises of differing durations and intensities on heart rate and biochemical blood variables. J. Anim. Sci. 87: 3211-3217.

Misumi, K., H. Sakamoto and R. Shimizu. 1994. The validy of swimming training for two-year old thoroughbreds. J. Vet. Med. Sci. 56:217-222.

Misumi, K., H. Sakamoto and R. Shimizu. 1995. Changes in 
skeletal muscle composition in response to swimming training for young horses. J. Vet. Med. Sci. 57:959-961.

Piccione, G., G. Giannetto, F. Fazio, S. Di Mauro and G. Caola. 2007. Haematological response to different workload in jumper horses. Bulgarian J. Vet. Med. 10:21-28.

Piccione, G., V. Messina, S. Casella, C. Giannetto and G. Caola. 2010. Blood lactate levels during exercise in athletic horses. Comp. Clin. Path. 19:535-539.

Pluim, B. M., A. H. Zwinderman, A. van der Laarse and E. E. van der Wall. 2000. The athlete's heart. A meta analysis of cardiac structure and function. Am. Heart Assoc. 101:336-344.

Thomas, D. P., F. Fregin, N. H. Gerber and N. B. Ailes. 1980. Cardiorespiratory adjustments to tethered swimming in the horse. Pflugers Archiv European J. Physiol. 385:65-70.
Toubekis, A. G., A. Tsolaki, L. Smilios, H. T. Douda, T. Kourtesis and S. P. Tokmakidis. 2008. Swimming performance after passive and active recovery of various durations. Int. J. Sports Physiol. Perform. 3:375-386.

Waran, N. 2002. The welfare of horses: Welfare of the racehorse during exercise training and racing. In: Kluwer Academic publishers (Ed. D. L. Evans). Netherlands, p. 197.

Westerblad, H. and D. Allen. 2003. Cellular mechanisms of skeletal muscle fatigue. Advance in Experimental Medicine and Biology 538:563-570.

Young, L. E., D. J. Marlin, C. Deaton, H. Brown-Feltner, C. A. Roberts and J. L. N. Wood. 2002. Heart size estimated by echocardiography correlates with maximal oxygen uptake. Equine Exercise Physiology 6. Equine Vet. J. Suppl. 34:467471. 